\title{
A DISCOURSE ANALYSIS OF NEWS MEDIA ARTICLES ON THE POLISH 'RULE OF LAW CRISIS'
}

\section{STEPHEN DERSLEY, PhD Student}

Faculty of Anthropology and Cultural Studies

Adam Mickiewicz University, Szamarzewskiego 89, 60-568 Poznań, Poland steder@amu.edu.pl

\section{ORCID: https://orcid.org/0000-0002-6765-8590}

\begin{abstract}
The article identifies the discursive characteristics of news media texts covering Poland's 'constitutional crisis'. Following the conception of discourse presented in Laclau and Mouffe (1985), i.e. as an articulatory practice that conveys meaning through a structured system of positions and differences, the article highlights some features of English-language news media texts (e.g. from the Guardian, Telegraph, Economist, Financial Times, New York Times, Washington Post) that can be described as typical. The following features are identified: a lecturing tone, the use of structural oppositions, immediate rebuttals, misrepresentation, appeals to expertise, and the sovereignty taboo. These features are diagnosed as contributing to the narrow discursive range covered by news articles. To shed light on this narrow range, the article presents three conflicting positions from Polish legal theory
\end{abstract}


that address the issues of constitutional courts, the rule of law and national sovereignty: Ryszard Piotrowki's legal constitutionalism, Paweł Bała and Adam Wielomski's Schmitt-inspired position, and Adam Sulikowski's reading of the constitutional courts as an instrument of hegemonic discourse. In the conclusion it is suggested that news media discourse would benefit from demonstrating a greater awareness of other discourses, and from developing a more generous, balanced approach to presenting and addressing their claims.

Keywords: discourse analysis; news media articles; the Polish constitutional crisis; rule of law; sovereignty; legal theory.

\title{
ANALIZA DYSKURSYWNA PUBLIKACJI PRASOWYCH DOTYCZĄCYCH „KRYZYSU PRAWORZĄDNOŚCI” W POLSCE
}

\begin{abstract}
Abstrakt: W artykule wskazano charakterystyczne cechy dyskursu publikacji prasowych poświęconych „kryzysowi konstytucyjnemu” w Polsce. Bazując na koncepcji dyskursu autorstwa Laclaua i Mouffe (1985), zgodnie z którą jest to praktyka artykulacyjna wyrażająca znaczenie poprzez ustrukturyzowany system pozycji i różnic, zwrócono uwagę na pewne typowe cechy tekstów publikowanych w prasie anglojęzycznej (np. w The Guardian, Telegraph, Economist, Financial Times, New York Times, Washington Post). Są to: pouczający ton, wykorzystanie strukturalnych przeciwieństw, natychmiastowe odpieranie zarzutów, przeinaczanie, odwoływanie się do wiedzy eksperckiej oraz swoistego tabu suwerenności. Wykazano, że cechy te przyczyniają się do zawężania zakresu dyskursu tychże publikacji. Następnie, celem wskazania zakresu zawężenia anglojęzycznego dyskursu prasowego, artykuł zwięźle przedstawia trzy odmienne stanowiska z obszaru polskiej teorii prawa. Podejmują one kwestie sądów konstytucyjnych, praworządności i suwerenności narodowej. Stanowiska te to konstytucjonalizm prawny Ryszarda Piotrowskiego, podejście Pawła Bały i Adama Wielomskiego, zainspirowanych teorią Schmitta, oraz interpretacja Adama Sulikowskiego, w myśl której sądy konstytucyjne są instrumentami dyskursu hegemonicznego. We wnioskach zasygnalizowano, że dyskurs publikacji prasowych istotnie skorzystałby na uwzględnieniu innych dyskursów oraz rozwinięciu bogatszego i bardziej zrównoważonego podejścia do sposobu, w jaki prezentuje i odnosi się do zawartych w nich stwierdzeń.
\end{abstract}

Slowa kluczowe: analiza dyskursu; dyskurs prasowy; kryzys konstytucyjny w Polsce; praworządność; suwerenność; teoria prawa. 


\section{Introduction}

\subsection{The issue}

Over the course of 5 years, Poland's 'rule of law crisis' or 'constitutional crisis', as it is referred to in English news media and scholarship, ${ }^{1}$ has become immensely complex and deeply divisive. The crisis essentially concerns the steps taken by the Polish government and President, after the Law and Justice Party came to power in October 2015, with regard to the judicial power (the Constitutional Tribunal, the Supreme Court, the ordinary courts and the National Council of the Judiciary), which has taken the form of appointments, mandatory retirements and legislation on structure and organisation. The conflict boils down to the constitutionality of the government's legislation and president's actions, and whether the principles of the separation of powers and judicial independence have been breached. The crisis became an EU issue when the European Commission acted to "defend judicial independence" in December 2017 (European Commission 2017), and with the EU Court of Justice ruling in January 2020 that Poland had failed to fulfil its obligations under EU law.

From the outset, the crisis has been extensively covered in UK and US publications representing positions across the political spectrum. Coverage has persisted through Covid-19 pandemic, with reference being made to the crisis in editorials in the Guardian and Telegraph on Poland's presidential election of May-July 2020, ${ }^{2}$ and then in commentary on the 'abortion ban' of October $2020 .^{3}$

In UK and US news sources, the Polish 'rule of law crisis' is treated as symptomatic of more general trends, with Poland frequently being positioned as further along the lurch into illiberalism and authoritarianism. In US publications, the purpose of the focus on Poland is often to warn and trigger reflection, as in Anne Applebaum's piece

\footnotetext{
${ }^{1}$ For a scholarly account of the crisis, see Bunikowski (2018).

2 See 'The Guardian view on Poland's presidential election: call it off' Guardian 05.05.2020, and 'Poland's Law and Justice party needs to start living up to its name' Telegraph 12.07.2020.

3 Author's note: the furore surrounding Contitutional Tribunal's ruling on abortion erupted after this article was submitted for review, therefore newspaper articles covering this issue fall outside the scope of the present work.
} 
for the October 2018 issue of The Atlantic, 'A Warning from Europe: The Worst is Yet to Come'. In UK newspapers, the Polish crisis has been leveraged to bolster positions and push agendas on Brexit - prior to the Covid-19 pandemic perhaps the most polarizing issue in UK media discourse. Two articles - one from The Guardian, the other from The Telegraph, and thus from newspapers supposedly at the opposite ends of the political spectrum - exemplify this tendency.

In February 2019, in an opinion piece for the UK's pro-Brexit Telegraph, Damien Phillips, a conservative public affairs consultant, ${ }^{4}$ argued 'A no-deal Brexit is our safest option to escape the EU police state - let's go for it'. To support the description of the EU as a police state, the author provides details on a surveillance scandal in Romania, alleging that the EU has shown "wilful blindness" to this issue. For further evidence, Phillips then details the "abuses of power" of two EU member states - Hungary and Poland:

\begin{abstract}
Meanwhile, in Hungary, we see ever more centralisation of power and authority, with judges being forcibly retired in large numbers, political figures given greater control of the judiciary and even the establishment of courts overseen directly by government. In Poland, the state has clamped down on the judiciary, press and civil rights - in violation of its constitution and Polish law. Independent courts and mutual recognition of legal decisions between member states are central to the operation of EU law and the single market, prompting legal analysts to declare Hungary and Poland as posing a far worse threat to the EU than Brexit (Phillips 2019).
\end{abstract}

Thus, the UK's exit from the EU without a trade deal is justified because: a) the EU is becoming "ever more centralised"; and yet, b) its "ostensibly rules-based order" is being challenged and undermined by the authoritarian tendencies of certain member states. The EU is thereby cast as a centralised police state, but also one which refuses "to face up to the peril of a steady collapse in the rule of law in many of its member states" (Phillips 2019) (emphasis added).

Over a year later, in March 2020, the Warsaw-based Annabelle Chapman ${ }^{5}$ wrote a report-opinion piece for the pro-EU Guardian, arguing that 'Poland's leadership doesn't need "Polexit" - it can undermine the EU from within'. Like Phillips, Chapman pairs Poland

\footnotetext{
${ }^{4}$ See Phillips' articles for ConservativeHome and his Twitter activity.

5 See Chapman's Twitter for links to her articles in The Economist and other publications.
} 
with Hungary and asserts that Poland's Law and Justice party (PiS) is undermining the rule of law in the EU through its dealings with the judiciary:

\begin{abstract}
Poland has been locked in a protracted conflict with EU institutions over its judicial changes, which the European commission has warned undermine the rule of law. Together with Hungary's prime minister, Viktor Orbán, PiS has challenged the idea that liberal democracy is the only game in town and normalised values typically associated with the far right, including disbanding a government body that dealt with racism and xenophobia and championing homophobia. But the most substantial threat to the EU comes from PiS's capture of the judiciary. [...] If they remain unaddressed, the Polish government's judicial changes could have a wider impact on the rule of law in Poland and the EU (Chapman 2020, emphasis added).
\end{abstract}

The point to be addressed here is how two journalists, writing from opposite positions on the currently most defining and divisive issue in UK politics, could at the same time adopt nearly identical positions on Poland's 'rule of law crisis'. In other words, even if their agendas concerning the EU are opposed, the authors are nevertheless united in their descriptions of the steps taken by the Polish government in its dealings with the judiciary. Their consensus is that the Polish government is undermining the rule of law in Poland and the EU; and that PiS poses a broad threat to liberal democracy in Europe. In neither text is any effort made to explore the motivations and justifications for PiS's reforms of the judiciary; neither is any attempt made to investigate PiS's ostensible challenge to liberal democracy: Chapman acknowledges there may be another "game in town", but reduces it to the irrational fears of xenophobia and homophobia.

In terms of discourse theory, both journalists can be viewed as occupying positions in the same discourse, and then, more broadly, in the same discursive formation.

\title{
1.2. Definitions and assumptions
}

For the purposes of this article, discourse is defined, following (Laclau and Mouffe 1985), as an articulatory practice that constitutes a meaning-system constructed through "a differential and structured 
system of positions" (Laclau and Mouffe 1985: 105), and a discursive formation can be identified if "certain regularities establish differential positions" (Laclau and Mouffe 1985: 109).

The articulatory practice of writing genre-typical newspaper texts draws on a structured system of contingently fixated meanings, naturalized categories and relational identities to constitute subject positions within a broader field of "discursive struggle" (Jorgensen and Phillips 2002: 6). If certain regularities (textual features, strategies) are observed to permeate across genres - in this case newspaper articles and editorials, scholarly legal theory and normative texts (constitutions, treaties and legal rulings) - then such regularities can be identified as belonging to a discursive formation: a complex of intertextual articulatory practices and material institutions.

Unlike Foucault (1972) and Fairclough (1992), Laclau and Mouffe do not distinguish between discursive and non-discursive practices (1985: 107-109): they treat discourse as having a material aspect, in the sense that parliaments, courts, prisons, a judge's role and position, lawyers' offices, legal costs etc., are all part of legal discourse, just as much as textual phenomena (constitutions, bills, amendments, theoretical texts, newspaper articles), since they are structured by systems of signification and meaning.

Lastly, and most importantly, in Laclau and Mouffe's discourse theory, the existence of a discourse is grounded in antagonism: a discourse attempts "to dominate the field discursivity" (Laclau and Mouffe 1985: 112), and articulatory practices confront each other "in a field criss-crossed by antagonisms", from which hegemony emerges (Laclau and Mouffe 1985: 114, 134). Just as they view identities as being constructed relationally, through differential subject positionings, the same goes for discourses and discourse formations: they require a frontier and something "beyond them", an exteriority, in order to constitute themselves as a totality (Laclau and Mouffe 1985: 143). In other words, a discourse (e.g. legal constitutionalism) or a discursive formation (e.g. the liberal-democratic legal order) can only constitute and define itself by the antagonistic suppression (negative definition, misrepresentation) of that which they are not (e.g. populism). 


\subsection{Methodology}

As Fairclough (1992: 57) and Jorgensen and Phillips (2002: 49) observe, the broad, macro-level approaches of Foucault and of Laclau and Mouffe do not provide examples of, or tools for, detailed text analysis. Thus, while the present article is grounded in the philosophical conception of discourse developed by Laclau and Mouffe, the methodology for the detailed analysis of news media articles draws on the insights and approaches of Fairclough $(1992,1995)$ and van Dijk (2009, 2014).

For Fairclough, discourse analysis is necessarily "a multidisciplinary activity" (1992: 74), since it oscillates between the descriptive analysis of textual properties and the interpretation of texts produced and consumed as a part of social practice. While textual properties can be analysed with the tools of linguistics, in particular those provided by Halliday's functional approach $(2003,2014)$, the tools of sociology are necessary for interpreting the socio-cognitive process involved in text production and consumption, particularly with regard to how this practice is shaped by and construct meaning through interpretation (Fairclough 1992: 71-75).

Fairclough's multidisciplinary approach is extended by van Dijk (2014), who argues that, since discourse shapes the knowledge acquired and continually updated by espistemic communities, discourse studies should draw on the various disciplines that account for knowledge production and consumption. For van Dijk, "discourse analysis is not a method but a cross-discipline"; hence, in addition to sociology, it can employ the methods of psychology, anthropology, communication studies, linguistics, semiotics etc., in order to shed light on the "knowledge-discourse interface" (van Dijk 2014: 7-12).

With this in mind, Section 2 of this article adopts a genre-based approach to the discourse analysis of news texts covering Poland's 'constitutional crisis'. The analysis is restricted to broadsheet and weeklies, for the simple reason that tabloid newspapers have not covered this issue with any regularity. ${ }^{6}$ Texts which address this issue

\footnotetext{
${ }^{6}$ When tabloid newspapers (e.g. The Sun, The Mirror and New York Post) cover Poland, the articles tend to focus on other issues (migration, abortion, broader conflict with the EU). For example, The Sun mentioned the Constitutional Tribunal following the October 'abortion ban'. See: https://www.thesun.co.uk/news/13005047/poland-banabortions-clashes-cops-warsaw/
} 
are assigned to three main types: reports, editorials/opinion pieces, and blends of reports and opinion pieces. These text types are treated as constituting a system of genres, in their configuration and relationships (Fairclough 1992: 126). The texts thus assigned are then analysed to identify genre-typical features. A feature is treated as potentially typical if it appears in several texts and in different publications, thereby suggesting its systemic nature.

The method of textual analysis employed here is both descriptive, e.g. when focusing on the use of adjectives and modality, and interpretative, e.g. when highlighting the use of strategies, such as appeals to expertise, immediate rebuttals etc. It is assumed, following Fairclough, that texts are produced and consumed by social agents thorugh socio-cognitive processes that are largely unconscious: writers employ strategies to convey meaning, and readers construct meaning through interpretation (Fairclough 1992: 71-2; 1995: 233). The consideration of such strategies necessarily entails moving from the description of textual elements to interpretation of the factors that determine textual production.

Section 3 presents three conflicting positions from Polish legal theory that address the issues covered or suppressed by the articles analyzed in Section 2. The purpose in this section is not to analyse these theoretical texts in terms of genre features, but rather - following Fairclough and van Dijk's multi- and interdisciplinary discourse studies - to analyse the texts using the key tool from the discipline of philosophy, i.e. the analysis of concepts. The aim is to juxtapose divergent conceptions of the constutional judiciary, the rule of law, and sovereignty, which are currently the subject of much debate in Polish legal theory, with a view to shedding light on the narrow conceptual range found in the articles analysed in Section 2.

While it is simply impossible for a researcher to adopt a privileged standpoint outside of discourse per se (Jorgensen and Phillips 2002: 21), a researcher can consider the relationship and interaction between discourses, such as news media and legal theory, and analyse how a concept is presented and treated in both.

Thus, to return to the articles of Phillips and Chapman, despite the fact they articulate divergent subject positions from within the opposed corporate-subject positions of the Guardian and the Telegraph, they can be seen as deploying the same "naturalised categories" (Jorgensen and Phillips 2002: 21-26) to organize their statements and texts in similar ways. For example, in both articles, 'the 
rule of law' is invoked as a common-sense, taken-for-granted category: it is not explicated or contextualized to any extent. Chapman (2020) merely describes the rule of law as one of the EU's "fundamental values" and refers the reader via a hyperlink to the European Commission's Rule of Law webpage; ${ }^{7}$ elucidation is thereby outsourced to the experts. In turn, Phillips contrasts the "rules-based order" of the EU, characterised as centralized and tyrannical, with the UK's "liberty under the law". It is possible that Phillips' distinction alludes to deeper differences between continental law and the UK's common law, but the juxtaposition is not clarified or developed, and remains purely rhetorical. For example, a Brexiteer could argue that the UK's common law principle of 'rule of law', based on a balance between parliamentary sovereignty and 'judge-made law' whereby legislation is applied in accordance with an open, evolving, unwritten constitution (Santoro 2007: 153-200), is fundamentally incompatible continental concepts of 'rule of law' (Etat de droit, Rechtsstaat and praworzadność), which are based on the supremacy of closed constitutions and the control of constitutional courts. Yet Phillips makes no such argument.

With these Guardian and Telegraph articles, the lack of elucidation can be interpreted in a variety of ways. Perhaps the authors assume their readers have sufficient knowledge of what the "the rule of law' is, and thus do not require a dumbed-down explanation. Or perhaps the meaning of this concept is - deliberately or unconsciously - swept under the carpet, so the expression can function as an empty signifier, thus foreclosing reflection and discouraging deeper analysis on the part of the reader.

7 https://ec.europa.eu/info/policies/justice-and-fundamental-rights/upholding-rulelaw/rule-law_en 


\section{Generic features of news media texts on Poland's 'constitutional crisis'}

\subsection{Text types: the reporting/commenting continuum}

UK and US news texts covering Poland's 'constitutional crisis' can be viewed as occupying a continuum ranging from relatively neutral reports of events to overt commentary in the form of editorials and opinion pieces. In between these two text types there are increasingly common blends of reporting and commenting.

\subsubsection{Reports}

Texts which can be placed on the reporting end of the continuum can firstly be distinguished by what they do not do. This negative definition is exemplified in in the language used to describe the chief actors. Thus in the BBC articles 'Poland reverses law on removing judges following EU court ruling', 21.11.2018, and 'Retirement age: Poland broke EU law with ruling on judges', 5.11.2019, the descriptions of the Polish government avoid the adjectives 'right-wing', 'populist' and 'nationalist', which are typical of opinion pieces; instead the following terms are used: "Poland's governing party", "the government", "The Law and Justice Party (PiS)", "the PiS".

The most descriptive premodification appears in the noun phrase "Poland's socially conservative government" (5.11.2019). I would argue that this is a more neutral premodification than 'rightwing populist' or 'nationalist', as the description signals there are different types of conservatism, and thus has an informative function, rather than a trigger function.

Other actors are described as follows: "the head of the PiS, Jaroslaw Kaczynski", "the Supreme Court chief justice, Professor Malgorzata Gersdorf"; whereas in opinion pieces and blends the same actors are described as "rightwing firebrand Jaroslaw Kaczynski" (Shotter and Majos 2019) and "the independent-minded Supreme Court president" (The Economist 2020). 
Another genre-typical feature of such reports is the attempt to include the multiple viewpoints, through a mixture of direct and indirect speech, without commenting on the perspectives or developments. Thus, despite the dramatic headline of the Express article 'Brussels fury: Poland could be KICKED OUT of EU over controversial reforms', 19.12.2019, the actual text refrains from commenting, and attempts to present the varied perspectives of PiS representatives, the Court of Justice of the EU, protesters etc. The only opinions that the author offers concern probability ("the legislation is likely to pass") (Mowat 2019). ${ }^{8}$

\subsubsection{Editorials/opinion pieces}

Editorials on Poland's 'constitutional crisis' have appeared in the pages of the Financial Times and The Guardian. One of the typical features of this text type is the lecturing, paternalistic tone adopted, and the extensive use of modality to comment on what certain actors should do or should refrain from doing.

For instance, in the Financial Times article 'Poland must not slide further into illiberalism', 16.10.2019, the editorial team offers the following advice: "Law and Justice would do better to build on its popularity while trying to heal the country's divisions" (emphasis added). In the article 'In Poland, the rule of law is under ever greater threat', 09.02.2020, the team advises the Polish government: "If the Polish government's real aim is to provide more effective justice, it would do better to backtrack" (emphasis added); and EU states: "Above all, EU states should not shrink from linking future disbursement of lucrative structural funds to upholding the rule of law" (emphasis added).

Similarly, the Guardian editorial 'The Guardian view on Poland's presidential election: call it off', 05.05.2020, which connects the Presidential election to Law and Justice "playing fast and loose with democratic norms, particularly in relation to the judiciary and media", concludes that the election should be called off, stating: "On legal,

\footnotetext{
${ }^{8}$ For a similar range of viewpoints, see the Agence France-Presse article published in the Telegraph on 4.7.2018, 'Polish Supreme Court chief justice turns up to work in defiance of retirement law being challenged by EU'
} 
logistical and ethical grounds that would be the right course of action" (emphasis added). ${ }^{9}$

This paternalistic lecturing is grist to the mill for nationalistoriented assertions that the institutions of Western Europe - such as the EU, the Court of Justice of the European Union, multinationals and, of course 'Western media' - are tools of colonialism. ${ }^{10}$ The fact that the editorial boards of UK newspapers take it upon themselves to tell Polish political parties and EU states what course of action they should take does seem to testify to the presence of an entitled mindset; one that presumes its Central European addressees will pay heed.

\subsubsection{Blends of factual news reports and opinion pieces}

The paternalistic, lecturing tone is also distinctive textual feature typical for blends of reports and commentary. Such texts also employ a range of other strategies which, due to their regularity, can be identified as genre-typical features.

The first is mixing verifiable facts with value-laden language designed to trigger associations and emotions. A case in point is Marc Santora's article 'Polish Crisis Deepens as Judges Condemn Their Own Court' for the New York Times, 05.07.2018, which opens as follows:

For days, tens of thousands of Poles have marched in the streets to protest their nationalist government's purge of the Supreme Court, an action that has been condemned by the European Union as a threat to the rule of law in a country that led the struggle against Soviet domination in 1989 (Santora 2018).

\footnotetext{
${ }^{9}$ It would be worth exploring whether this lecturing tone is unique to 'Western' newspapers commenting on Poland. Preliminary research on Polish articles commenting on, for example, Brexit or Boris Johnson's clashes with the Supreme Court of the United Kingdom (i.e. the UK's own 'constitutional crisis') suggest that Polish dailies and weeklies do not take it upon themselves to lecture the UK. For instance, see "Sąd Najwyższy ratuje honor brytyjskiej demokracji. Co dalej z brexitem? [The Supreme Court saves the honour of British democracy. What's next for Brexit?]", Polityka 24.09.2019 (Skarżyński 2019); and "Brexit - lekcja dla Polski [Brexit - a lesson for Poland]" Gazeta Wyborcza 31.01.2020 (Michnik 2020).

${ }^{10}$ See, for example, Ferenc Almassy's article "Eastern Europeans Begin to Grow Tired of Western Colonialism" (Almassy 2017).
} 
In the midst of statements of identifiable and verifiable facts (a large number of Poles marched in protest; the Polish government's actions were criticized by the EU) there are some statements that are more problematic. First, the description of a government as "nationalist" has negative connotations in this context, since the article is structured around a network of positive and negative actors, with "the European Union" being the positive counterpart to the Polish government. Second, the description of the government's action as a "purge" is neither informative nor neutral: the reader is not given any information - at this point - on what exactly the government has done to the Supreme Court; and when the term 'purge' is deployed shortly before the reference to Soviet domination in the final clause, the Polish government is thereby implicitly compared with the Soviet Union, which readers with even basic knowledge of communism will associate with Stalinist purges. This comparison is echoed in third paragraph, where Poland is described as "a nation that once represented postcommunist hopes for democracy but that is now under the grip of an increasingly authoritarian - though legitimately elected - government" (Santora 2018). Again, and somewhat obviously, the adjective "authoritarian" is deployed as the negative term, contrasted with "democracy".

The article also exemplifies another key strategy typical for this genre of texts on the Polish crisis: namely the presentation of a token argument which is immediately refuted by a counter argument (often drawing on anonymous, 'expert' sources), as can be seen in the following section:

\footnotetext{
The government says the reforms are all intended to make the courts more responsive to the will of the people - and to free the judiciary from corrupt judges or communist-era holdovers. But critics see the end of the judiciary's functioning as a check on power - and a violation of the liberal democratic norms that are required of members of the European Union, which Poland joined in 2004" (Santora 2018, emphasis added).
}

In an article consisting of 1,777 words, a total of 31 words are devoted to the government's justification of its actions ${ }^{11}$ - which is instantly subjected to a rebuttal ("But critics see...") that does not in fact respond

\footnotetext{
${ }^{11}$ A further 71 words are devoted to Zbigniew Ziobro's comments on the jurisdiction and competent of Court of Justice of the European Union, which appear at the end of the article and upon which no comment is made.
} 
to the government's reported claims (i.e. the courts need to be more responsive; the judiciary is corrupt), but instead resorts to hyperbole ("the end of the judiciary's functioning").

This strategy of immediate rebuttal is employed in the Washington Post article 'If you think the U.S. is having a constitutional crisis, you should see what is happening in Poland', 25.01.2020, but here, while Polish government sources are anonymous and the argument is summarized in reported speech, the rebuttal is clearly weighted towards the expertise and authority of Koen Lenaerts, whose argument is quoted directly:

PiS authorities argue that this is an instance of unwarranted European Union interference in domestic affairs. However, the European Union relies on cooperation between national and European courts, and E.U. membership requires respect for the rule of law, including judicial independence. As Koen Lenaerts, president of the European Court of Justice (the European Union's highest court), put it earlier this month in a debate at Warsaw University: 'You can't be a member of the European Union if you don't have independent, impartial courts operating in accordance with fair trial rule, upholding Union law"” (Pech and Kelemen 2020) (emphasis added).

Similar immediate rebuttals and tactical appeals to expertise can be found in the Financial Times article 'Poland's clash over justice system leaves courts in chaos' 24.01.2020, which cites five words of Zbigniew Ziobro, Poland's justice minister, and reports government sources anonymously ("Law and Justice argues ..."), while including a lengthy direct quotation from "Marcin Matczak, a law professor at the University of Warsaw", and concluding the article by citing "Christian Wigand, a spokesman for the commission..." (Shotter 2020). ${ }^{12}$

\footnotetext{
12 That the use of such textual tactics is not inevitable when covering Polish controversies is demonstrated by reports that address broader social and political issues (in addition to the 'constitutional crisis'), such as the Times article 'Inflamed Poland scorns Brussels', 06.08.2017 (Pancevski 2017), and the Financial Times article 'Poland election: the unfinished counter-revolution', 09.10.2019 (Shotter and Majos 2019). These reports - while still resorting to genre-typical dramatic phrases ("waging an unprecedented all-out war", "the PiS-loathing urban elite" (Pancevski 2017), "rightwing firebrand Jaroslaw Kaczynski" (Shotter and Majos 2019)) - can be described as reasonably balanced: multiple points of view are presented, with the use of direct quotations; and commentary is either kept to a minimum or is extrapolated from the interviewees' words.
} 


\subsection{Implicit oppositions}

As has been mentioned, the discourse of news media articles on the Polish 'constitutional crisis' is structured around naturalised categories and value-laden structural oppositions that can be taken for granted in the interactive generation of meaning, and thus for consolidating assumptions and reinforcing opinions. While previous sections have highlighted how some of these categories and pairs operate in their textual context, below they are presented in a de-contextualized form.

Table 1. A selection of oppositions occurring in newspaper articles on the Polish 'constitutional crisis'.

\begin{tabular}{|c|c|}
\hline & \\
\hline \multicolumn{2}{|c|}{$\begin{array}{l}\text { Polish Crisis Deepens as Judges Condemn Their Own Court (New York Times, } \\
\text { 05.07.2018) (Santora 2018) }\end{array}$} \\
\hline rule of law, the European Union & $\begin{array}{l}\text { nationalist government; increasingly } \\
\text { authoritarian; }\end{array}$ \\
\hline $\begin{array}{l}\text { post-communist } \\
\text { democracy }\end{array}$ & Soviet domination \\
\hline $\begin{array}{l}\text { judicial independence; once- } \\
\text { impartial tribunal; a non-partisan } \\
\text { group }\end{array}$ & $\begin{array}{l}\text { purge of the Supreme Court; politicized } \\
\text { and dysfunctional; increasingly } \\
\text { politicized; stacked with its own jurists; } \\
\text { rigged }\end{array}$ \\
\hline \multicolumn{2}{|c|}{$\begin{array}{l}\text { A no-deal Brexit is our safest option to escape the EU police state - let's go for } \\
\text { it (The Telegraph, 08.02.2019) (Phillips 2019) }\end{array}$} \\
\hline 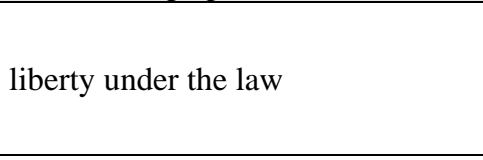 & $\begin{array}{l}\text { the EU police state; a dark and insidious } \\
\text { authoritarianism; backsliding ing } \\
\text { authoritarianism; the forces of } \\
\text { conservatism and denial }\end{array}$ \\
\hline $\begin{array}{l}\text { stitution and Polish law; } \\
\text { ndent courts; our legal } \\
\text { y }\end{array}$ & \\
\hline \multicolumn{2}{|c|}{$\begin{array}{l}\text { Poland must not slide further into illiberalism (Financial Times, 16.10.2019) } \\
\text { (Financial Times 2019) }\end{array}$} \\
\hline $\begin{array}{lr}\text { estern liberals; } & \text { civil } \\
\text { ntrist fightback; } & \text { cradle of } 1989 \\
\text { ti-communist } & \text { uprisings; } \\
\text { estern capitals; the centre-right }\end{array}$ & $\begin{array}{l}\text { illiberalism; Conservative nationalism; } \\
\text { nationalist populism; Catholic-infused } \\
\text { social conservatism; a form of one-party } \\
\text { rule; its abrasive leader, Jaroslaw } \\
\text { Kaczynski; illiberal quasi- } \\
\text { authoritarianism fostered by Mr. Orban; }\end{array}$ \\
\hline & $\begin{array}{l}\text { neuter the constitutional court; } \\
\text { contentious legal reforms; tinker with } \\
\text { electoral rules }\end{array}$ \\
\hline
\end{tabular}




\begin{tabular}{|c|c|}
\hline \multicolumn{2}{|c|}{$\begin{array}{l}\text { Law and Justice v law and justice (The Economist, 25.01.2020) (The Economist } \\
\text { 2020) }\end{array}$} \\
\hline $\begin{array}{l}\text { concerns over the rule of law; a } \\
\text { union made of laws }\end{array}$ & $\begin{array}{l}\text { sowing chaos; an expression from } \\
\text { communist times: lex telefonica }\end{array}$ \\
\hline $\begin{array}{l}\text { the European Commission; the } \\
\text { ECJ; the Venice Commission }\end{array}$ & $\begin{array}{l}\text { the populist Law and Justice; Hungary's } \\
\text { ruling Fidesz Party }\end{array}$ \\
\hline politically tainted & $\begin{array}{l}\text { an independent jurists' association; the } \\
\text { independent-minded Supreme Court } \\
\text { president }\end{array}$ \\
\hline \multicolumn{2}{|c|}{$\begin{array}{l}\text { If you think the U.S. is having a constitutional crisis, you should see what is } \\
\text { happening in Poland (Washington Post, 25.01.2020) (Pech and Keleman) }\end{array}$} \\
\hline $\begin{array}{l}\text { the European Commission has } \\
\text { escalated its efforts to defend } \\
\text { judicial independence; }\end{array}$ & $\begin{array}{l}\text { the PiS government has sought to exert } \\
\text { control over judges; }\end{array}$ \\
\hline $\begin{array}{l}\text { E.U. membership requires respect } \\
\text { for the rule of law, including } \\
\text { judicial independence. }\end{array}$ & "a Soviet-style justice system" \\
\hline \multicolumn{2}{|c|}{$\begin{array}{l}\text { In Poland, the rule of law is under ever greater threat (Financial Times, } \\
\text { 09.02.2020) (Financial Times 2020) }\end{array}$} \\
\hline The EU is built on the rule of law & $\begin{array}{l}\text { Hungary's nationalist government; PiS } \\
\text { swiftly neutered Poland's Constitutional } \\
\text { Tribunal; chaos now threatens; }\end{array}$ \\
\hline Independent experts & $\begin{array}{l}\text { loyalist judges; attempts to cow the } \\
\text { judiciary }\end{array}$ \\
\hline \multicolumn{2}{|c|}{$\begin{array}{l}\text { Poland's leadership doesn't need 'Polexit' it can undermine the EU from within } \\
\text { (The Guardian, 10.03.2020) (Chapman 2020) }\end{array}$} \\
\hline liberal democracy & $\begin{array}{l}\text { The rightwing populist Law and Justice } \\
\text { Party; the country's rightwing leadership }\end{array}$ \\
\hline the fundamental values of the EU & $\begin{array}{l}\text { values typically associated with the far } \\
\text { right; championing homophobia }\end{array}$ \\
\hline $\begin{array}{l}\text { the rule of law in Poland and the } \\
\text { EU }\end{array}$ & $\begin{array}{l}\text { capture of the judiciary; undermining the } \\
\text { rule of law }\end{array}$ \\
\hline \multicolumn{2}{|c|}{$\begin{array}{l}\text { Poland's Right-wing populists tested by close-run presidential race (The } \\
\text { Telegraph, 29.06.2020) (Day 2020) }\end{array}$} \\
\hline centre-Right mayor of Warsaw & populist Right-wing president \\
\hline $\begin{array}{l}\text { outward looking; at ease with } \\
\text { liberal values }\end{array}$ & a defender of the "traditional family" \\
\hline repair relations with Brussels & $\begin{array}{l}\text { of the country's judicial system; } \\
\text { ning the constitutional order }\end{array}$ \\
\hline
\end{tabular}


This is not to suggest that there is in all cases a strict, direct one-to-one correspondence between the positive and negative sides in the table rows. The authors structure their texts around a network of oppositions, and seek to convey meaning through strategies and techniques, but how this meaning is constructed is dependent on the interpretative skills and inclinations of readers. In other words, it falls to the reader to couple the oppositions latent in the text and form binary pairs in the process of interpretation.

Since Laclau and Mouffe's 1985 model lacks a clear account of the reader's role in discursive practices, Fairclough and van Dijk can be called upon to plug the theoretical gap.

Fairclough's social theory of discourse, practice is comprised of three processes: production, distribution and consumption (Fairclough 1992: 71). In his terminology, texts "are made of forms which past discursive practice, condensed into conventions, has endowed with meaning potential". This meaning potential is reduced by interpreters, who ascribe their selected meanings in the process of reading/interpretation (Fairclough 1992: 75). For Fairclough, both the production of meaning potential in texts and the ascription of meaning in interpretation are determined by social factors and contexts. Hence the forms that the authors of newspaper articles use to produce their meaning potential are determined by past discursive practice, but also by the collective nature of newspaper text production (Fairclough 1992: 78). Teun A. van Dijk develops this further with his socio-cognitive context model of how context determines discursive communication, thus:

The journalist writing an editorial at the same time may engage in institutional and political action, and does so as member of a media organization, as member of a professional group, and probably as a member of one or more ideological groups. When writing the editorial she thus not only instantiates a general activity of newspaper editors but also the social representations shared by the organization or groups she currently "identifies" with (van Dijk 2009: 80).

The same goes for the consumption/interpretation of newspaper articles: how a reader processes the forms embodied in a text will depend on their social context (ideological leanings, socio-cultural groups, identities and identifications). The authors of newspaper articles are able to draw on this social context to make assumptions about their readers' general knowledge and political leanings. 
What is striking in the articles under consideration, however, is the regularity of the structural oppositions used, and across newspapers occupying varied and opposed positions on the political spectrum. This discursive regularity adds weight to the argument made in Section 1: that the positions articulated on Poland's 'constitutional crisis' stake out and constitute a narrow discursive field. The regularities suggest that beneath the intense divisions of left vs. right, leave vs. remain, authors and readers are united in their antagonism towards a more fundamental enemy, which is depicted as illiberal populism that undermines the rule of law.

In Laclau and Mouffe's model, 'discursive fixations' function in a similar way to Fairclough's 'forms', in the sense that they are regularities that are arrested or delimited from the surplus of meaning. Since in their conception meaning is always overdetermined, all identities and meanings are only ever partial: they are "the relative and precarious forms of fixation which accompany the establishment of a certain order" (Laclau and Mouffe 1985: 98). Thus, in Laclau and Mouffe's 1985 model, rather than a theory of specific discourse production and consumption, the emphasis is on the precarious, unstable nature of discourses and the subject positions constituted within them. But if this abstract model is applied to concrete discourse, this entails that, as an articulatory practice, the writing of newspaper articles that address and participate in social antagonisms is dependent on rearticulation: as events unfold and other discourses continue and develop their articulations in response to them, the unstable frontiers of a discourse and discourse formation require incessant reconstitution and delimitation. Oppositions are continually reiterated in discursive confrontation, both in the process of text production and in the interpretative process of text consumption. If the notion of "discursive struggle" is taken seriously (Jorgensen and Phillips 2002: 6), then newspaper opinion pieces on social-political crises are involved in just such a struggle. Furthermore, if Laclau and Mouffe's notion of hegemonic discourse is accepted, then the structural oppositions deployed in news media discourse have to be understood as reflecting deep-seated social antagonisms. 


\subsection{Direct confrontation and misrepresentation}

In addition to implicit structural oppositions and the strategy of immediate rebuttal, an article from the print edition of The Economist: 'Law and Justice v law and justice', 25.01.2020, also employs the strategy of misrepresentation, and this is related to another typical feature of news media texts covering Poland's 'constitutional crisis', namely a systemic avoidance of the issue of sovereignty.

The Economist article focuses on the conflict between the Polish government, the Polish Supreme Court and the ECJ, following the Supreme Court's request, in August 2019, for a preliminary ruling from the ECJ on the Polish government's law creating a disciplinary chamber for the Court. While the first half of the article provides a summary of these complex developments, the second half presents the justifications put forward by the Polish government. Rather than analyzing these justifications in any degree of detail, each argument is followed by an immediate rebuttal. The first example:

The government says it is being treated unfairly. Under EU treaties, says Andrzej Duda, the president, "Poland has the right to regulate its internal legal order." The opposite is closer to the truth. The treaties oblige national courts to apply EU law and obey the ECJ. European officials and experts in EU law warn that if one country's courts are politicised, others may stop accepting their rulings" (The Economist 2020) (emphasis added).

The rebuttal does not substantially address the claim made by the president: it merely asserts the opposite, before citing anonymous experts to put forward a conditional claim which: a) equates a country's assertion of sovereignty over its own legal order with the politicization of its courts; b) draws on the unquestioned assumption that national courts are by default non-politicized; and c) suggests the possible negative consequences of such politicization to the efficacy of the ECJ. The argumentation is tangential in the most generous light; in the worst, it is an example of rhetorical obfuscation masquerading as balanced argument while clearly siding with EU interests.

The Economist article proceeds to tackle three arguments ostensibly put forward by the Polish government in its 'White Paper on the Reform of the Polish Judiciary', which was presented to the President of the European Commission, in March 2018. In discursive 
terms, this can be treated as an example of news media discourse engaging with an exterior discourse. The strategies employed in this confrontation are immediate rebuttal, suppression, misrepresentation and appeals to expertise.

The rebuttal strategy is employed to present and dismiss the first government justification:

One was that the courts had never been properly de-communised. Three decades after the transition, this seems dubious. The average judge is far too young to have served under the communist regime. The government undermined its own case in November by appointing to the constitutional court and elderly PiS lawmaker who had served as a notorious prosecutor for the old dictatorship" (The Economist 2020) (emphasis added).

By focusing on "the average judge", the rebuttal ignores the fact that the justification in the White Paper is focused on specific judges, and concludes by listing examples of the specific sentences that had been issued by judges now sitting on the Supreme Court when they had been sitting in the lower courts during the period of martial law (White Paper 2018: $15-16) .{ }^{13}$

This government justification is tackled more convincingly by Iustitia, the Polish Judges Association, in its 'Response to the White Paper Compendium', 16.03.2018. The Association acknowledges that there are indeed 6 Supreme Court judges who adjudicated in courts of lower instance during the period of martial law (1982-1983), out of a total staff of 93, but suggests that if they are to be accused of "unworthy conduct" and brought to justice, this would have to be done on the basis of "an individualized (criminal or disciplinary) appraisal". Iustitia concludes that the Polish Government's systemic reform of the Supreme Court resulting in "the dismissal of $40 \%$ of the judges is a completely disproportionate measure" (Iustitia 2018: §4).

This response from Iustitia would have been available to the authors of the Economist article, with a modicum of research, since it was published on the association's website, in English, 9 days after the publication of the Polish Government's White Paper, and thus over 18 months before the publication of the Economist article. And the

\footnotetext{
${ }^{13}$ References are to page numbers, rather than sections or paragraphs. The White Paper is organized into numbered paragraphs, but there is some text which is not numbered (e.g. in panels).
} 
Economist article actually mentions Iustitia's protest march which took place in January 2020.

The validity of the second government justification is acknowledged, but then immediately rebutted by citing the opinions of anonymous judges: "Another argument is that cases take too long [...] Backlogs are indeed long, but judges say the reforms will not shorten them. They have not added support staff or simplified procedures much" (emphasis added). Thus, the rebuttal acknowledges the validity of the justification but shifts to criticism of the remedy.

The third and final "claim" that the Economist authors chose to focus on is not actually presented in the White Paper as a justification for the reforms, but is actually a response to the "European Commission's Remarks against the backdrop of the Legal System in Poland and in other EU Member States". Therein, Polish Government responds, point-by-point, to the Commission's assertion that its reforms of the judiciary constitute a threat to the rule of law in Poland. Describing these arguments as one of the "three justifications for its reforms" simply misrepresents the Polish Government's White Paper. In fact, the third justification offered by the Polish Government is that the reforms restore balance to the tripartite separation of powers. This far-reaching argument, involving issues of accountability, immunity and judicialization, is entirely ignored by The Economist. Needless to say, the argument is addressed in Iustitia's 'Response' (\$7).

Nevertheless, The Economist asserts:

\begin{abstract}
A third claim is that the EU is biased against eastern European countries, since western ones also give governments some say in the judiciary. For example, in Germany, as in Poland, the president of the constitutional tribunal is picked by the government, and cases are heard by smaller panels of judges. But in Poland the court's president gets to select the panels and can choose loyal PiS justices (Economist 2020, emphasis added).
\end{abstract}

The use of the term "eastern European countries" sets off alarm bells, since by most accounts Poland is located in Central Europe, and a search of the White Paper reveals that at no point does the Polish Government complain of bias against "eastern European countries", and neither is any mention is made of 'western' countries. Furthermore, the White Paper makes no reference to the president of the German Constitutional Tribunal being picked the government. In the White Paper, comparisons with Germany are made with regard to: the 
regulations on "trainee judges", or "a judge on probation" (38-39, 4548); the absence of a National Judiciary Council in Germany (54); the nomination of judges by commissions composed of politicians (64-66); and judicial self-governance (84). Thus, The Economist simply misrepresents the White Paper and ignores the key arguments put forward.

What the White Paper does assert is that the government's reforms are "are in harmony with long-standing standards in other European Union countries" (underlining and emphasis in the original) (25). The White Paper concedes that "Polish regulations are not an exact copy of the Spanish, British, German or French legislation", but:

\begin{abstract}
It is completely natural for the legal regimes of specific EU Member States to differ. Such differences stem from distinctive national and legal identities, which are protected by the European Union's treaty law. However, those differences are not significant enough (e.g. mechanism of appointing judicial members for the National Council of the Judiciary varies from Spanish system only in details) to warrant claims that solutions resembling regulations that have proved themselves in other EU countries for years (and that have never presented any threat to the rule of law) should violate the tripartite separation of powers in Poland (White Paper 2018: 25-26).
\end{abstract}

The Polish Government's arguments thus appeal to the respect for national identities enshrined in Article 4 of the Treaty on European Union - identities which are "inherent in their fundamental structures, political and constitutional"; and insist that the EU Member States have "separate constitutional identities" (83). Ultimately, the White Paper is an assertion of national sovereignty, proposing that Article 4's principle of respect for national identities should allow for "constitutional pluralism" (81):

The right to introduce its own sovereign institutional solutions concerning the judiciary is a pillar of each national constitutional system in Europe. The Polish reforms of the judiciary implement this right - they have been carried out in a way that takes into account the need to remedy the defects of the domestic judicial system, and at the same time does not diverge in a significant way from solutions that are universally applied in the European Union countries" (White Paper 2018: 83).

The crucial issue of sovereignty is simply not addressed in The Economist article. 
Instead, the misrepresented Polish government's claim that the EU allows western governments to "have some say in the judiciary" is immediately rebutted with a reference to cherry-picking by Hungary, and then two "experts" are named in an appeal to expertise: Kim Lane Scheppele, to provide the term "Frankenstate", which describes a state composed of borrowed institutions and solutions; and Kees Sterk, president of the European Network of Councils for the Judiciary, to assert that people with knowledge of the systems in Europe are not fooled by the action of the Polish Government. The main thrust of the argumentative strategy is then made explicit: "Such complex manoeuvres may fool lay people, but not the experts" (The Economist 2020).

Rather than misrepresenting and suppressing the Polish Government's arguments, and rebutting them with superficial appeals to expertise, The Economist could have tackled the justifications openly and head-on. For example, in its response to the sovereignty assertion, Iustitia argued that the Polish Government's reforms of the judiciary fall outside the autonomy protected by Article 4 of the Treaty on European Union. ${ }^{14}$ However, The Economist seems to assume that "lay people" are incapable of understanding such point-by-point argumentation and at the same time employs discursive strategies that make it more unlikely that "lay people" will access such arguments. The near-imperceptible blend of reporting and opinion-shaping contributes to the dumbing-down of an already narrow discursive field. ${ }^{15}$

\subsection{Internal discursive policing and the sovereignty taboo}

The Economist article discussed in the last section revealed the lengths some journalists will go to in order to avoid addressing the assertion of sovereignty in the Polish context. I would go as far as to assert that a

\footnotetext{
14 "The assumption underlying the autonomy of constitutional identity is that the Member State itself abides by the principle of patere legem quam ipse fecisti, according to which an authority is bound by its own rules and, in particular, its own Constitution. Therefore, breaching one's own constitutional rules is a denial of the principle of constitutional pluralism and its resulting decision-making autonomy" (Iustitia: §26).

15 For another example of a refusal to engage with the Polish Government's White Paper, see Zselyke Csasky's article for Foreign Policy (Csasky 2018).
} 
reluctance to discuss this issue is a systemic feature of news media discourse focused on the Polish crisis.

This claim draws on Foucault's notion of "discursive "policing"" put forward in his 1970 Inaugural Lecture "The Order of Discourse" (Foucault 1981: 56-61). While Foucault preceded Laclau and Mouffe in defining discourse as a practice which employs the principle of exclusion to distinguish itself from other, exterior discourses, he also posited that discourses are practices constituted by procedures that impose internal constraints and exercise control of the discursive interior. Thus, scientific discourse is controlled by disciplines: internal principles that define what objects a given discourse can speak of; what a science can decide is true or false (Foucault 1981: 59-60).

I suggest that the concept of internal discursive policing can be applied to news media discourse: there are certain topics and concepts that simply cannot be spoken of in this discourse, and in UK and US news media discourse that addresses the Polish 'constitutional crisis' evidence suggests that the concept of sovereignty is taboo. Even articles published by stridently pro-Brexit UK newspapers such as the Telegraph and Express tend to avoid the issue of national sovereignty when discussing Poland's clashes with the European Commission, despite the fact that the UK's sovereignty vis-à-vis the EU and the European Court of Human rights has been a defining and oft-discussed issue in articles focused on Brexit.

As we have seen (1.1), Damien Phillips argued in his 2019 Telegraph article that a no-deal Brexit was the best way for the UK to escape from the "EU police state" (Phillips 2019), and Poland and Hungary were depicted as extreme representatives of a growing authoritarian tendency. Thus, while urging the UK to protect its sovereign institutions, e.g. "We must [...] shield our legal integrity from those EU states who are regressing into ever-deeper authoritarianism" (Phillips 2019), at no point does Phillips open the discursive space to allow consideration of the possibility that Poland's actions may also viewed as attempt to shield its legal integrity from the EU. At a fundamental level, the sovereignty exercised through Brexit is cast as a reclamation of British liberty ("with liberty under the law as our guiding principle" (Phillips 2019)), which must be disassociated from illiberal assertions of sovereignty, to the point where the latter are not even acknowledged as having anything to do with sovereignty. 
Support for this hypothesized sovereignty taboo is provided by two articles by Peter Foster, the Telegraph Europe Editor. The first, entitled 'What would Brexit mean for British sovereignty?', appeared on 08.06.2016, just over two weeks before the Brexit referendum. Here, Foster outlines why EU law has supremacy over UK law, comments on the extent of EU law, and then provides a balanced and cautious breakdown of "the key areas where the EU currently impinges on UK sovereignty and how much sovereignty the UK could reclaim if we voted to leave" (Foster 2016). He covers a range of areas, including agriculture, justice, trade and immigration. Rather than present a simplistic, buccaneering image of sovereignty, Foster acknowledges the complexity of the issue and treats it pragmatically, pointing out that the UK cedes sovereignty in certain areas for the benefits that are gained.

Just over a year later, on 27.06.2017, the Telegraph published Foster's 'Poland's constitutional crisis threatens to pull EU apart'. Here, Foster generally frames the Polish crisis as a challenge to "the EU's integrationist ambitions" and focuses on the EU's response. The article is divided into a series of 8 questions, 5 of which explicitly focus on the EU: So what is the EUdoing about it? What's so 'nuclear' about Article 7? So is Article 7 an empty threat? So the EU will just stand idly by? So is there anything the EU can do? (Foster 2017). Only one section presents the crisis from the Polish perspective: So liberal democracy is dying in Poland? Foster's answer:

\footnotetext{
It's not as simple as that. As a counterpoint it is worth noting that, contrary to the overwhelming Western media narrative, the ruling Law and Justice party's reforms ideas are not, in themselves, necessarily anti-democratic if handled differently (Foster 2017).
}

This is an intriguing stance. On the one hand, Foster recognizes there is a discursive hegemony that frames Poland's reforms as antidemocratic, but on the other hand stops short of allowing that these reforms may be part of a rejection of liberal democracy, though not democracy per se. For Foster, the Polish reforms of the judiciary, "if handled differently", "if framed properly", can be presented and viewed as democratic. In other words, the agency of the Polish government is reduced to framing the issue in a certain way, to convincing the EU that its reforms are similar the process of judicial appointments in "mature democracies" such as Germany, Norway and the US (Foster 2017). 
When discussing the EU's threat to trigger Article 7, Foster actually broaches the subject of sovereignty:

\begin{abstract}
The Commission wants to 'act', but by doing so it risks hitting the EU's biggest nerve: to what extent should a supra-national body of dubious democratic legitimacy be able to intervene in the internal affairs of a member state? (Foster 2017).
\end{abstract}

Here, sovereignty is revealed as the crux of the matter, but it is framed from the EU's perspective, rather than from the perspective of the member state: the question is to what extent can the EU intervene, not to what extent can a member state assert its legal autonomy and integrity within the EU framework.

In more centrist or left-leaning UK and US commentary the issue of sovereignty is regularly avoided through reference to "the rule of law'.

In 1.1, we saw how Anabelle Chapman, in her Guardian article, reduced Law and Justice's agenda to normalizing "values typically associated with the far right", such as homophobia and xenophobia, and how this characterization is swiftly followed by the following claim: "And by undermining the rule of law, Warsaw is eroding one of the fundamental values that the EU was founded upon" (Chapman 2020). No effort is made to explore the Polish government's agential motivations, which are simply depicted as reactionary and destructive. As the same time, the rule of law is both positioned as fundamental and left entirely unexplored.

A similar strategy is employed in Joanna Berendt's New York Times article 'E.U. Court Rules Poland Must Suspend Disciplinary Panel for Judges' 08.04.2020. This time, the word 'sovereignty' actually appears in the text, when the author quotes a Twitter statement from the Polish deputy justice minister, Sebastian Kaleta, who responded to the CJEU's ruling as follows: "Today's ruling is an act of usurpation violating Poland's sovereignty". ${ }^{16}$ The issue of sovereignty is not addressed elsewhere in the text. Instead, the author draws on a range of experts (three judges and one professor) and institutions that express their concerns: in their lengthy direct quotations, Judge Krystian Markiewicz, Professor Artur Nowak-Far and Judge Stanislaw Zablocki focus on "the rule of law", "a community of law" and "the

${ }^{16}$ The original tweet: https://twitter.com/sjkaleta/status/1247813390426398721 
values considered to be the foundation of European law", respectively (Berendt 2020).

In my view, this evasion of the issue of national soveriegnty is both perplexing and regrettable - as is explained in the Conclusion.

\section{Insights on the rule of law and sovereignty from Polish legal theory}

This section will explore three different positions expressed in Polish legal theory on the crisis. As was mentioned in 1.3, the primary aim here is to shed some light on the narrow range of positions articulated in the articles analysed in the previous sections.

\subsection{Ryszard Piotrowski's legal constitutionalist approach}

Professor Ryszard Piotrowski's essay 'Judges and the Limits of Democratic Power in the Light of the Constitution of the Republic of Poland', published in Ruch Prawniczy, Ekonomiczny i Socjologiczny in 2018, provides a lucid account of the rule of law and sovereignty in the Polish system from the perspective of liberal-democratic constitutional theory. In essence, Piotrowski shows how the Polish system fits into the European system of treaties and institutions in which, following the horrors of nationalism experienced during the Second World War, the rule of law effectively places limits on national sovereignty, by curbing the power of the parliamentary majority.

Piotrowski cites the Polish Constitution, its Preamble and a Constitutional Tribunal ruling to remind his readers that the Constitution itself posits the principle of "the inherent and inalienable dignity of the person" as the foundation of the system of the Republic of Poland and as the source of rights and freedoms. All other principles - e.g. a democratic state ruled by law, the separation of powers - are all subordinate to this founding principle. According to Piotrowski, this value does not derive from any legal act: human beings possess certain rights "simply by virtue of being born a human being"; rights which are 
"not dependent on the will of the legislator" and thus lie beyond its reach (Piotrowski 2018: 215).

This is the liberal component of liberal democracy: the rights of the individual are protected from the power of the demos. While the continental rule of law model, largely developed by German jurists in the $19^{\text {th }}$ century, as the doctrine of Rechtsstaat, was designed to protect civil society and the individual from the power of the sovereign state, after the experience of National Socialism and fascism, and in particular with the unlimited power of the Nazi state as representative of the Volk, the post-war rule of law doctrine designed solutions to protect the individual from the potential abuses of democracy (Costa 2007: 123133; Piotrowski 2018: 222). One such solution was Hans Kelsen's institution of constitutional courts, which are authorized to review legislation in terms of its compatibility with constitutions.

Piotrowski emphasizes that in the system of the Republic of Poland, the judicial power is "the guardian of universal and timeless values": it safeguards these values from the parliamentary majority and, furthermore, if parliament forgets these values in the legislative process, the judicial power is legitimized to make corrections (Piotrowski 2018: 217). The Polish Constitution stipulates that the judicial power is a separate and independent power (Art. 173), and, according to Piotrowski, it assigns a specific role to the Constitutional Tribunal, namely that of guarding "the limits of national sovereignty" (Piotrowski 2018: 222). Thus, crucially, in Piotrowski's model, the Constitution limits national sovereignty, since it assigns sovereignty to the values upheld by the community of the European Union, and since the Constitutional Tribunal is endowed with the authority to review domestic legislation and international agreements in terms of their intercompatibility (Art. 188 Constitution RP), judges are "becoming the depositaries of the Nation's sovereignty" and can represent the sovereign (Piotrowski 2018: 222). The increasing importance of the judiciary after European integration has entailed a corresponding decrease in the role of parliament, placing "the judge above the legislator" (Piotrowski 2018: 222).

Thus, in Piotrowski's account, the conflict between PiS and the judicial power boils down to issues of soveriegnty and legitimacy. Under the control of PiS, the legislative and executive powers, which derive their mandate to represent the will of the Nation from elections, are being employed in an attempt to wrest sovereignty from the guardianship of the judicial power and the values of the European 
community (Piotrowski 2018: 223-4). The judicial power draws its independence and its legitimacy to represent the Nation from the Constitution (Piotrowski 2018: 223-4), which is an instrument of the rule of law; and therefore any interference with the independence of the judiciary by definition undermines the rule of law.

Piotrowski's essay articulates a position within the liberaldemocratic rule of law tradition of continental Europe, the discourse of which is now thoroughly institutionalized in the courts, treaties and jurisprudence of the European Union and the European legal order. This discourse defines itself as purposely designed to limit the legislative and executive powers.

\subsection{Pawel Bala and Adam Wielomski's challenge to "liberal-democratic dogma"}

On 12 December 2015, Dr. Paweł Bała and Professor Adam Wielomski published an article Rzeczpospolita entitled "Lawyers on the Constitutional Tribunal Controversy: Who is the Guardian of the Constitution?", ${ }^{17}$ which basically argued that the President of the Republic of Poland, rather than the judicial power, is the true guardian of the Polish Constitution.

Bała and Wielomski's argument is extrapolated from the presidential address given by President Andrzej Duda on 3 December 2015, following the swearing in of five PiS nominated judges to the Constitutional Tribunal at a midnight ceremony on 2 December. The president's words are used to reject the Rousseau-Montesquieu-Kelsen model of the rule of law (combining the general will, the separation of powers, and constitutional courts), with an alternative RousseauConstant-Schmitt model (will of the people/Nation, direct delegation and the executive power as a Schmittian sovereign).

The president's statement "I was guided by the will of the newly elected Sejm, in which Poles put such great hope for the repair of the Republic of Poland" is read as asserting, implicitly, that the 'naród' (people, nation) is sovereign, and that this sovereign has

${ }^{17}$ The original title: Prawnicy o sporze wokót TK: Kto jest obrońca konstytucji? 
delegated power to the Sejm (parliament). This leads to the following conclusion:

In this vision, the will of the Nation stands above individual constitutional provisions. If the sovereign says 'I want', neither the Constitutional Tribunal, nor any other organ of the state can answer: 'You cannot, because your will is inconsistent with the constitution or laws"” (Bała and Wielomski 2015).

This account of sovereignty is therefore fundamentally opposed to that presented by Piotrowski in 2018: it is suggested that the will of the people/Nation, expressed through parliament, cannot be constrained by either the Constitution or the judicial power. Once the will of the people is placed above the Constitution, the legitimacy of the judicial power is weakened, and when viewed through the Rousseauan notion of delegation, the Sejm is viewed as receiving its mandate directly from the people, and is thus a direct delegate, but "the judges of the constitutional court [...] are delegate of delegates" (Bała and Wielomski 2015).

The authors interpret the president's claim to be "safeguarding the Constitution and the continuity of state power" to propose that the President is the true guardian of the Constitution, rather than the Constitutional Tribunal. They draw on Art. 126 (2) of the Constitution RP ("The President of the Republic shall ensure observance of the Constitution") and Carl Schmitt's constitutional theory to suggest that when President Duda told the Polish nation "In order to put an end to the unnecessary disputes undermining the authority of the key institutions of the Polish State [...] I decided to take the oath from the judges [...]", he was acting as a Schmittian sovereign - the "custodian of institutionalized violence" who makes "political decisions supported by real political categories" (Bała and Wielomski 2015).

Bała and Wielomski draw on Schmitt's famous dictum that "Sovereign is he who decides on the exception" (Schmitt 1985: 5) to suggest the essence of power lies with the President of the Republic, the commander of the armed forces, rather than with "deliberation, verdicts, court decisions" (Bała and Wielomski 2015). Like the Sejm, the president is also a direct delegate, but one to whom the Nation has conferred the power to defend the Republican form of government.

In their concluding paragraphs, the authors make no bones about the conflict taking place between PiS and the judicial power: the 
denial of the Constitutional Tribunal's power to restrain the legislative power is an attack on the Kelsenist conception of the role of constitutional courts and, more broadly, on liberal democracy. However, Bała and Wielomski do not go as far as to assert that this attack on liberal democracy is an attack on democracy per se: "It is therefore a misunderstanding that the one who does not accept the vision of a 'negative legislator' automatically negates the essence of a democratic state ruled by law" (Bała and Wielomski 2015). Their suggestion is that a new "political system" could be emerging, one in which the will of the Nation-sovereign is directly represented by the legislative and executive powers.

Since their text is a provocative newspaper article, Bała and Wielomski conclude with hints and leave many questions unanswered, not least of which is how their proposed political system - with the legislative and executive powers controlled by one political party and the president as guardian of the Constitution - would be compatible with the rule of law, if the essence of the rule of law is that power is restrained by law? And how could such a system be compatible with the legal order of the European Union?

In discursive terms, it is significant that two Polish jurists felt comfortable with publicly invoking Carl Schmitt - the German jurist who notoriously supported the Nazi party and Hitler's seizure of power in 1933 - to support their notion that power should be wrested from the judicial power and transferred to the executive. In this respect, Bała and Wielomski are by no means alone: the rehabilitation of Schmitt is a characteristic of theoretical-political discourse on both the right and left these days (see Mouffe 2005; Burns 2020), in the search for alternatives to liberal-democratic thought. ${ }^{18}$

\subsection{Adam Sulikowski's critique of neutrality}

Professor Adam Sulikowski's critique of the institution of constitutional courts, such as that made in "Constitution - System Hegemony" (Sulikowski 2016), is grounded in an anti-Kelsenist stance which draws on Schmitt's juristic theory and Chantal Mouffe's revised

\footnotetext{
${ }^{18}$ On the issue of Schmitt and Polish legal theory see (Bunikowski 2018).
} 
Schmittian concept of 'the political'. Crucially, Sulikowski's arguments come from a complex philosophical position which is decidedly left of centre.

Sulikowski's central thesis is that nothing escapes 'the political', especially judicial organs such as constitutional courts. The concept of 'the political' posits that the basis of social life is antagonism, organized around 'the friend/enemy' distinction (Schmitt 1996: 26-27). According to both Schmitt and Mouffe, this antagonism is "ineradicable" (Mouffe 2005: 4-5); it is the ontological or existential antithesis at the heart of social life. Societies are viewed as being organized according to collective groupings, with the possibility of violence ever present. Peace and the operation of law require that this antagonism is sublimated and masked, but in emergency situations the Schmittian exception - legal norms evaporate, and the contingent nature of the legal order and the identity of the true sovereign become apparent (Schmitt 1985: 12-13).

The notions of contingency and hegemony are of particular importance for Sulikowski. Mouffe argues that every social order is the result of sedimented practices "that conceal the originary acts of their contingent political institution and which are taken for granted, as if they were self-grounded" (Mouffe 2005: 17). Thus, a social order appears to be entirely natural, necessary and inevitable, when in fact it is "the temporary and precarious articulation of contingent practices. [...] Things could always be otherwise and therefore every order is predicated on the exclusion of other possibilities" (Mouffe 2005: 18). This exclusion is the basis for hegemonic discourse.

Sulikowski posits that "that the constitutional judiciary is an embodiment of Enlightenment bourgeois ideology based on a certain rationalistic/liberal set of assumptions about law" (Sulikowski 2016: 253). In other words, rather than being paragons of impartiality and independence, constitutional courts are inherently and ineradicably mired in 'the political', though this fact generally escapes our attention or is forgotten. Constitutional courts employ the "juristic camouflage" of deductive argumentation and interpretative rules "to effectively mask the extra-legal motivations behind decisions" (Mouffe 2005: 256). These extra-legal motivations only become apparent when the legislative power attempts to introduce acts which conflict with the values upheld by the constitutional judiciary, or which are embodied in the constitution and its case law. Sulikowski cites the rulings 
concerning the so-called abortion compromise (1997) and the lustration rulings (1998) (Sulikowski 2016: 258). ${ }^{19}$

According to Sulikowski, when there is a stable consensus, the assumption that law is neutral is reinforced by the media and "apologetic scholarly discourses" (Sulikowski 2016: 258). Drawing on the perspective and terminology of Laclau and Mouffe's discourse theory, Sulikowski casts the constitutional courts as deploying empty signifiers, such as "freedom", "equality" and "justice", and filling them with content through hegemonic interventions. Thus, rather than the guardians of universal, timeless values, as Piotrowski would have it, the constitutional courts are "the guardians of the hegemonic power over the content of empty signifiers" (Sulikowski 2016: 260).

The rise of populist movements, as an eruption of the existential, emotional antagonism animating the political, is therefore depicted - following Laclau and Mouffe - as a rejection of the liberaldemocratic discursive hegemony: its individualistic values, its institutions, and its legal order. And this rejection can be cast as arising from a perceived lack of democracy, rather than an attack on democracy. The populist identification of enemies "is usually accompanied by a sense of disillusionment and a lack of true democracy - the ritualised 'acquis constitutionnel' ceases to appear to certain social groups as something pure, non-ideological and objective, and begins to be seen as dominated by enemies or at best too tolerant for them" (Sulikowski 2016: 261).Thus, the attack on the Constitutional Tribunal and the judiciary in Poland can be viewed as grounded in a wholesale rejection of the rule of law ideology that enshrines these institutions as impartial and independent counterweights to the will of the majority (popular/pplebiscitary democracy).

\section{Conclusion}

It can be argued that Poland's 'constitutional crisis' or 'rule of law crisis' is, at its heart, a sovereignty crisis. As I mentioned at the end of 2.4, the fact that this aspect of the issue is evaded or suppressed is

\footnotetext{
${ }^{19}$ For an analysis of lustration in Poland, see "Polish lustration and the models of transitional justice" (Krotoszyński 2014).
} 
somewhat perplexing. In both Anglo-American and continental constitutional theory, the concept of the rule of law is inseparable from conceptions of soveriegnty: the essence of the rule of law in all systems is that law is an instrument used to restrain the power of the sovereign (Costa 2007: 134-6). Through the statements of its representatives and in the justifications presented in its documents, the Polish government has explicitly sought to frame the crisis in terms of sovereignty, but English language news media articles have failed to respond to this. Whether one views the Polish government's arguments as cynical or sincere, they need to be presented and addressed, not caricatured or suppressed.

If the news media articles cited and discussed in Sections 1 and 2 are mapped against the theoretical positions on the Polish 'constitutional crisis' outlined in Section 3, they all, despite their divergences, fit inside the theoretical space staked out by Piotrowski's article. In other words, they articulate positions firmly embedded within the discursive formation of liberal democracy. This, of course, is not to say that there is anything wrong with journalists articulating the values of liberal democracy. This practice becomes problematic, however, when these values are articulated with a lack of critical awareness or as part of a strategic simplification.

When a crisis of great complexity is presented through takenfor-granted, naturalized categories (e.g. invoking the concept of the rule of law without contextualization or elucidation, avoiding the related concepts of sovereignty and legitimacy), this amounts to doing readers a disservice. Rather than informing and persuading, such writing tends to misinform and manipulate, especially if other positions (i.e. based on assumptions and values other than those underpinning liberal democracy) are strategically caricatured, misrepresented or denied. News media discourse would greatly benefit from demonstrating a greater awareness of other, exterior discourses and developing a more generous and balanced approach to presenting and addressing their claims. 


\section{References}

Agence France-Presse. 2018. Polish Supreme Court Chief Justice Turns up to Work in Defiance of Retirement Law Being Challenged by EU (July 4). https://www.telegraph.co.uk/news/2018/07/04/polishsupreme-court-chief-justice-turns-work-defiance-retirement/ (accessed August 11, 2020).

Almassy, Ferenc. 2017. Eastern Europeans Begin to Grow Tired of Western Colonialism (September 14). https://visegradpost.com/en/2017/09/14/eastern-europeansbegin-to-grow-tired-of-western-colonialism/ (accessed August $13,2020)$.

Applebaum, Anne. 2018. A Warning From Europe: The Worst Is Yet to Come (October). The Atlantic. https://www.theatlantic.com/magazine/archive/2018/10/polan d-polarization/568324/ (accessed August 7, 2020).

Bała, Paweł, and Adam Wielomski. 2015. Prawnicy o Sporze Wokół TK: Kto Jest Obrońcą Konstytucji? (December 12). Rzeczpospolita. $\quad$ https://www.rp.pl/Sedziowie-isady/312129996-Prawnicy-o-sporze-wokol-TK-Kto-jestobronca-konstytucji.html?cid (accessed September 8, 2020).

Bartkiewicz, Artur. 2019. Sąd Najwyższy: Decyzja o Zawieszeniu Parlamentu - Nielegalna (September 24). https://www.rp.pl/Brexit/190919400-Sad-Najwyzszy-

Decyzja-o-zawieszeniu-parlamentu---nielegalna.html?cid (accessed August 12, 2020).

BBC. 2018. Poland Reverses Law on Removing Judges Following EU Court Ruling (November 21). https://www.bbc.com/news/world-europe-46296859 (accessed August 17, 2020).

BBC. 2019. Retirement Age: Poland Broke EU Law with Ruling on Judges (November 5). https://www.bbc.com/news/worldeurope-50302102 (accessed August 17, 2020).

Berendt, Joanna. 2020. E.U. Court Rules Poland Must Suspend Disciplinary Panel for Judges (April 8). New York Times. https://www.nytimes.com/2020/04/08/world/europe/polandjudges-eu-court.html (accessed September 6, 2020). 
Stephen Dersley: A Discourse Analysis of News Media Articles...

Bunikowski, Dawid. 2018. The Constitutional Crisis in Poland, Schmittian Questions and Kaczyński's Political and Legal Philosophy. Journal of Contemporary European Studies 26 (3): 285-307, DOI: 10.1080/14782804.2018.1498771.

Chapman, Annabelle. 2020. Poland's Leadership Doesn't Need 'Polexit' - it Can Undermine the EU from Within (March 10). The

Guardian

https://www.theguardian.com/world/commentisfree/2020/mar/ 10/poland-polexit-eu-rightwing-law-justice-party-judiciary (accessed August 6, 2020).

Costa, Petro. 2007. The Rule of Law: A Historical Introduction. In The Rule of Law History, Theory and Criticism, by Pietro Costa and Danilo Zolo, 73-152. Dordrecht: Springer.

Csasky, Zselyke. 2018. It's Time to Play Hardball With Poland (March 14). https://foreignpolicy.com/2018/03/14/its-time-to-playhardball-with-poland/ (accessed August 16, 2020).

European Commission. 2017. Rule of Law: European Commission Acts to Defend Judicial Independence in Poland (December 20).https://ec.europa.eu/commission/presscorner/detail/en/IP_ 17_5367 (accessed July 27, 2020).

Fairclough, Norman. 1992. Discourse and Social Change. Cambridge: Polity Press.

Fairclough, Norman. 1995. Critical Discourse Analysis. The Critical Study of Language. London: Longman.

Financial Times. 2019. Poland Must Not Slide Further into Illiberalism

(October 16). https://www.ft.com/content/32fed8bc-ef5e11e9-bfa4-b25f11f42901 (accessed August 16, 2020).

Financial Times. 2020. In Poland, The Rule of Law is Under Ever Greater Threat (February 9). https://www.ft.com/content/d2390d6e-49a2-11ea-aeb3955839e06441 (accessed August 16, 2020).

Foster, Peter. 2016. What Would Brexit Mean for British Sovereignty? (June 8). The Telegraph. https://www.telegraph.co.uk/news/2016/05/19/how-does-theeu-impinge-on-british-sovereignty-and-if-the-uk-vot/ (accessed September 6, 2020).

Foster, Peter. 2017. Poland's Constitutional Crisis Threatens to Pull EU Apart (July 27). The Telegraph. https://www.telegraph.co.uk/news/2017/07/26/special-report- 
polands-constitutional-crisis-threatens-pull/ (accessed September 6, 2020).

Foucault, Michel. 1972. The Archaeology of Knowledge. Transl. A.M. Sheridan Smith. United Kingdom: Tavistock Publications Ltd. Foucault, Michel. 1981. The Order of Discourse. In Untying the Text, ed. Robert Young, 48-77. Boston: Routledge \& Kegan Paul.

Halliday, Michael A.K. 2003. The Functional Basis of Language (1973). In On Language and Linguistics, ed. Jonathan Webster, 298-322. London: Continuum.

Halliday, Michael A.K. 2014. Halliday's Introduction to Functional Grammar, revised by Christian M.I.M. Matthiessen. Oxon: Routledge.

Iustitia. 2018. Response to the White Paper Compendium on the Reforms of the Polish Justice System (March 16). https://www.iustitia.pl/informacje/2172-response-to-thewhite-paper-compendium-on-the-reforms-of-the-polishjustice-system-presented-by-the-government-of-the-republicof-poland-to-the-european-commission (accessed August 15, 2010).

Jorgensen, Marianne, and Loiuse J. Phillips. 2002. Discourse Analysis as Theory and Method. London: Sage Publications.

Krotoszyński, Michał. 2014. Polish Lustration and the Models of Transitional Justice. Adam Mickiewicz University Law Review 3: 199-211.

Laclau, Ernesto, and Chantal Mouffe. 1985. Hegemony and Socialist Strategy. London: Verso.

Michnik, Adam. 2020. Brexit - Lekcja dla Polski (January 31). https://wyborcza.pl/7,75399,25650336,brexit-lekcja-dlapolski.html (accessed August 13, 2020).

Mowat, Laura. 2019. Brussels Fury: Poland Could be KICKED OUT of EU over Controversial Reforms (December 19). https://www.express.co.uk/news/world/1219112/eu-newspoland-supreme-court-judicial-reforms-law-and-justice (accessed August 11, 2020).

Pancevski, Bojan. 2017. Inflamed Poland scorns Brussels (August 6). The Times. https://www.thetimes.co.uk/article/inflamedpoland-scorns-brussels-7zwnzf817 (accessed September 6, 2020).

Pech, Laurent, and R. Daniel Kelemen. 2020. If You Think The U.S. Is Having a Constitutional Crisis, You Should See What Is 
Stephen Dersley: A Discourse Analysis of News Media Articles...

Happening in Poland (January 25). Washington Post. https://www.washingtonpost.com/politics/2020/01/25/if-youthink-us-is-having-constitutional-crisis-you-should-see-whatis-happening-poland/ (accessed September 6, 2020).

Phillips, Damien. 2019. A No-Deal Brexit Is Our Safest Option to Escape The EU Police State - Let's Go for It (February 8). Telegraph.

https://www.telegraph.co.uk/politics/2019/02/08/no-dealbrexit-safest-option-escape-eu-police-state/ (accessed August 6, 2020).

Piotrowski, Ryszard. 2018. Judges and the Limits of Democratic Power in the Light of The Constiution of The Republic of Poland. Ruch Prawniczy, Ekonomiczny i Socjologiczny Rok LXXX zeszyt 1 :

215-229,

https://pressto.amu.edu.pl/index.php/rpeis/article/download/12 639/19348/ (accessed August 8, 2020).

Rybarczyk, Marek. 2019. Sąd Najwyższy Ratuje Honor Brytyjskiej Demokracji. Co Dalej z Brexitem? (September 24). https://www.polityka.pl/tygodnikpolityka/swiat/1925930,1,sad -najwyzszy-ratuje-honor-brytyjskiej-demokracji-co-dalej-zbrexitem.read (accessed August 12, 2020).

Santora, Marc. 2018. Polish Crisis Deepens as Judges Condemn Their Own Court (July 5). New York Times. https://www.nytimes.com/2018/07/05/world/europe/polandcourt-crisis-constitutional-tribunal.html. (Accessed August 13, 2020).

Schmitt, Carl. 1985. Political Theology (transl. George Schwab). Chicago: The University of Chicago Press.

Schmitt, Carl. 1996. The Concept of the Political (transl. George Schwab). Chigaco: University of Chicago Press.

Shotter, James, and Agata Majos. 2019. Poland election: the Unfinished Counter-Revolution The Law and Justice Party Has Overseen Growth While Mobilising Voters Who Feel Left Behind (October 9). https://www.ft.com/content/176e701c-e8ec-11e985f4-d00e5018f061 (accessed August 17, 2020).

Stanisław Skarżyński. 2019. Sąd Najwyższy Jednomyślnie Posłał Johnsona na Deski. 'Zawieszenie Parlamentu Jest Bezprawiem i Jest Bezskuteczne (September 24) https://wyborcza.pl/7,75399,25229136,sad-najwyzszy- 
jednomyslnie-poslal-johnsona-na-deski-prorogacja.html. (accessed August 12, 2010).

Sulikowski, Adam. 2016. „Konstytucja - System - Hegemonia. „(Anty)Polityczna” Funkcja Argumentów Systemowych w Orzecznictwie Konstytucynym" Przeglad Prawa $i$ Administracji 104: 251-263.

The Economist. 2020. Law and Justice v Law and Justice (January 25). London: The Economist Newspaper Limited.

The Guardian. 2020. The Guardian View on Poland's Presidential Election: Call It off. (May 5). https://www.theguardian.com/commentisfree/2020/may/05/th e-guardian-view-on-polands-presidential-election-call-it-off (accessed August 7, 2020).

van Dijk, Teun A. 2009. Society and Discourse. Cambridge: Cambridge University Press.

van Dijk, Teun A. 2014. Discourse and Knowledge. Cambridge: Cambridge University Press.

White Paper on The Reform of The Polish Judiciary. March 72020. The Chancellery of the Prime Minister. https://www.premier.gov.pl/files/files/white_paper_en_full.pd f (accessed August 9, 2020). 